\title{
TOMASZ RAKOCZY \\ Zasady prawne ograniczające prawo wiernych do przyjmowania sakramentu Eucharystii
}

Okres od października 2004 do października 2005 r., na podstawie Listu Apostolskiego z dnia 7 października 2004 r. Mane nobiscum Domine, zostal ogloszony przez śp. Ojca Świętego Jana Pawla II Rokiem Eucharystii. Biskup Rzymu, we wskazanym dokumencie pisal m.in.: Lamanie chleba - jak na poczqtku nazywano Eucharystię - zawsze pozostaje w centrum życia Kościola. W przemijajacym czasie Chrystus uobecnia przez nie swa tajemnicę śmierci i zmartwychwstania. W niej daje się On nam w swej osobie jako »chleb żywy, który zstapil z nieba $(J 6,51)$, a wraz z Nim otrzymujemy zadatek życia wiecznego, w którym już teraz możemy kosztować wiekuistej uczty niebieskiego Jeruzalem ${ }^{1}$. W dalszej części cytowanego punktu Listu Apostolskiego Jan Pawel II stwierdza, że nie zamierzam powtarzać dawanych już wcześniej pouczeń i że: do nich tylko odsylam, zachęcajac do ich zglębienia i przyswojenia sobie ich treści. Ze wskazanych słów pouczenia wynika, że Biskup Rzymski odwoluje się do nauczania Kościola odnośnie do Eucharystii, nie wprowadzając żadnego novum. To wcześniejsze nauczanie zostało wyrażone chociażby w KPK z 1983 r., w którym papież, jako prawodawca powszechny bardzo gorąco zachęca wiernych do wlączenia się w przeżywanie Eucharystii. W kan. 897 nazwal Eucharystię Najbardziej Czcigodnym Sakramentem, do którego wierni, jak stanowi w kan. 898, winni odnosić się z największym szacunkiem. W szczególności mają oni brać czynny udzial w Jego sprawowaniu, przyjmując Go $z$ największą pobożnością i często oraz adorując Go z największą czcią.

Rodzi się jednak pytanie a contrario, a mianowicie czy istniejąjakieś zasady prawne, które ograniczają prawo wiernych do przystępowania do tego „Najczci-

\footnotetext{
${ }^{1} \mathrm{MnD} 3$.
} 
godniejszego Sakramentu". Mimo że KPK nie zawiera wprost katalogu takich zasad, to jednak o nich stanowi. Wymagają one wyinterpretowania. Na podstawie analizy przepisów prawnych dotyczących Eucharystii, można wyliczyć siedem zasad ograniczających prawo wiernego do Eucharystii. Pośród nich trzy wylączaja prawo wiernych do Eucharystii w ogóle; pozostale natomiast stawiaja wiernym pewne ograniczenia dotyczące przyjmowania Komunii św., nie wylączając jednak prawa do niej. Do pierwszej z grup należa: zakaz przyjmowania Eucharystii przez wiernych ukaranych, zakaz przyjęcia Eucharystii przez wiernych żyjących w grzechu ciężkim i obowiazzek przyjęcia Eucharystii od szafarza katolickiego. Do drugiej z grup należą: obowiazek zachowania postu eucharystycznego, przyjęcie Eucharystii raz dziennie, przyjęcie Eucharystii pod odpowiednią postacią i postawa towarzysząca przyjęciu Eucharystii. Omówienie niniejszych zasad stanowi treść artykułu.

\section{Zakaz przyjmowania Eucharystii przez wiernych ukaranych}

Prawodawca powszechny w kan. 915 KPK stanowi, że: Do Komunii Świętej nie należy dopuszczać ekskomunikowanych lub podlegajacych interdyktowi, po wymierzeniu lub deklaracji kary [...]. Zakaz ten dotyczy jedynie kar forum zewnętrznego, czyli sytuacji, gdy kara jest kara ferendae sententiae. Bezpośrednim i glównym adresatem wskazanej normy jest szafarz Eucharystii, który ma obowiązek odmówić udzielenia sakramentu. Pośrednio niniejsza zasada dotyczy wiernego, który ma obowiązek powstrzymania się od przystapienia do Komunii św. ${ }^{2}$.

Zakaz przyjmowania sakramentów, a zatem także i Eucharystii, nie dotyczy jedynie wiernych ukaranych na forum zewnętrznym tj. związanych skutkami kary ferendae sententiae. Wiąże on wiernych, którzy zaciagnęli karę latae sententiae. Wierni żyjący w karze, którą zaciagnęli z mocy samego prawa, także nie moga przystępować do sakramentów, a zatem konsekwentnie maja obowiązek powstrzymania się od przystapienia do Eucharystii. Wniosek taki plynie $\mathrm{z}$ analizy skutków, jakie wywiera ekskomunika czy interdykt latae sententiae, a które zostaly wpisane do kan. $1331 \S 1$ oraz $1332 \mathrm{KPK}^{3}$. Gdyby jednak, będąc w takiej karze, wierni okazali nieposluszeństwo prawu i przystapili do Eucharystii, szafarz, nawet majac świadomość wiązacej ich kary, nie może skorzystać z normy kan. 915 i odmówić im udzielenia sakramentu, ponieważ kara nie jest kara ferendae sententiae. Kodeksowy zakaz przystępowania do sakramentów w przypadku

${ }^{2}$ P. Hemperek, W. Góralski, F. Przy tuła, J. B a ka larz: Uświęcajace zadanie Kościola. W: P. Hemperek, W. Góralski, F. Przy tu la, J. B a ka larz: Komentarz do Kodeksu Prawa Kanonicznego z 1983 r. Lublin 1986 s. 121.

${ }^{3}$ A 1 t h a u s: Komentarz do kan. 915. W: Münstericher Kommentar zum Codex Iuris Canonici, Essen 1984 s. 915/2. 
kar latae sententiae zobowiązuje wiernego do powstrzymania się od przystępowania do sakramentów, ale jeszcze nie obowiązuje szafarza do odmowy ich udzielenia.

W przypadku kar latae sententiae obowiązek powstrzymania się przez wiernego od przystępowania do sakramentów świętych nie jest jednak bezwzględny. Chociaż kara wiąże wiernego, jak stanowi kan. 1351: wszędzie, także po ustaniu wladzy tego, kto karę ustanowil lub wymierzyl, chyba że co innego wyraźnie zastrzeżono, to prawo przewiduje dwa wyjątki od niniejszej reguly. Pozwalaja one na zawieszenie kary $w$ danym momencie. Pierwszy z nich zostal wpisany do kan. $1352 \$ 2 \mathrm{KPK}$. Jeśli przestępstwo kościelne nie jest notoryczne w miejscu przebywania przestępcy, wierny może zawiesić karę w niebezpieczeństwie poważnego zgorszenia lub znieslawienia siebie samego i w konsekwencji przystapić do Eucharystii. Podmiotem oceniającym zweryfikowanie się wymagan stawianych przez prawo jest sam wierny. On własna powaga zawiesza wykonanie ciążącej na nim kary. Chcąc zilustrować tę normę jakimś przykladem, można by wskazać na wiernego, który znalazł się we wspólnocie, nie świadomej zaciagniętej przezeń kary (wówczas kara nie jest notoryczna) i uczestniczy w Eucharystii ważnej dla niego $\mathrm{z}$ racji np. ślubu czy pogrzebu bliskiej osoby. W swojej subiektywnej ocenie nie przystępując do Komunii św., wierny mógłby spowodować sytuację poważnego znieslawienia samego siebie lub zgorszenia np. $\mathrm{z}$ tego względu, że jest bliskim krewnym. Należy domniemywać, że w takim przypadku zostalyby spelnione wymagania stawiane przez prawo i wierny mógłby przystapić do Komunii Eucharystycznej.

Drugi wyjątek od zasady obowiązywalności kary ma miejsce, w rozumieniu kan. $1352 \S 1$, w sytuacji niebezpieczeństwa śmierci wiernego. Zawieszeniu w takim przypadku ulega także kara zdeklarowana lub nalożona, nawet zastrzeżona, na czas tak dhugi, jak trwa niebezpieczeństwo śmierci. Podmiotem weryfikującym zaistnienie wymagań stawianych przez normę prawną jest samo prawo. Zawieszenie następuje w tym przypadku z mocy samego prawa.

Obecne prawo kanoniczne wylicza dziewięć przestępstw zagrożonych kara ekskomuniki latae sententiae. Spośród nich wiernych świeckich dotyczy pięć z nich. Sa one następujace: porzucenie, zabranie lub przechowanie postaci Eucharystycznych w celu świętokradczym (kan. 1367); użycie przymusu fizycznego wobec Biskupa Rzymskiego (kan. $1370 § 1$ ); odstępstwo od wiary (apostazja, schizma, herezja - kan. 1364 KPK); aborcja (kan. 1398); nagrywanie przy pomocy jakiegokolwiek urządzenia technicznego tego, co w spowiedzi sakramentalnej, prawdziwej lub symulowanej, własnej lub kogoś innego, jest mówione przez spowiednika lub przez penitenta czy upowszechnianie tego za pośrednictwem 
środków masowego przekazu (ekskomunika pozakodeksowa ${ }^{4}$ ). Dwa pierwsze przestępstwa są zastrzeżone Stolicy Apostolskiej. Pierwsze z wyliczonych przestępstw jest ponadto zastrzeżone Kongregacji Nauki Wiary ${ }^{5}$.

Kara interdyktu latae sententiae spotyka natomiast wiernego, który dokona jednego z czterech przestępstw: użycia przymusu fizycznego wobec biskupa (kan. 1370 \$2); usilowania sprawowania Ofiary Eucharystycznej bez świeceń kaplańskich (kan. $1378 \$ 2$ n. 1); usiłowania udzielenia rozgrzeszenia albo shuchania spowiedzi bez możliwości ważnego udzielenia rozgrzeszenia (kan. 1378 $\$ 2$ n. 2); falszywego oskarżenia spowiednika o naklanianiu do grzechu przeciwko szóstemu przykazaniu przed przełożonym kościelnym (kan. 1390 §1).

\section{Zakaz przyjmowania Eucharystii przez wiernych żyjących w grzechu ciężkim}

Niniejsza zasada różnicuje się na dwie. Pierwszą z nich jest zakaz przyjmowania Eucharystii przez wiernych żyjących w grzechu ciężkim, który nie nosi znamion jawności. Druga kategoria dotyczy wiernych żyjących w grzechu ciężkim jawnym. Od obu tych zasad istnieją wyjątki. Reguly te zatem nie wiążą bezwzględnie. Ten zakaz, jako jedyny z omawianych, wyplywa z prawa Bożego ${ }^{6}$.

\section{Wierni żyjący w grzechu ciężkim niejawnym}

Zakaz przyjmowania Eucharystii przez wiernych będących w stanie grzechu ciężkiego, a wlaściwie mających świadomość pozostawania w takim grzechu, wprowadzil prawodawca w kan. 916 KPK. Stanowi on, że: Kto ma świadomość grzechu ciężkiego, nie powinien bez sakramentalnej spowiedzi odprawiać Mszy świętej ani przyjmować Komunii Swiętej, chyba że istnieje poważna racja i nie ma sposobności wyspowiadania się. $W$ takim jednak wypadku ma pamiętać o tym, że jest obowiqzany wzbudzić akt żalu doskonalego, który zawiera w sobie zamiar wyspowiadania się jak najszybciej. Tradycyjna nauka Kościola stanowiaca o koniecznym wymaganiu wolności od grzechu ciężkiego w momencie przystapienia do Komunii św., zostala wyrażona w nauczaniu Soboru Trydenckiego, który domagał się, aby przyjęcie Eucharystii bylo poprzedzone wcześniejszym uzyskaniem absolucji sakramentalnej w sytuacji, gdy zaistnial grzech ciężki.

${ }^{4}$ AAS 80 (1988) 1367, tekst polski. W: W trosce o pelnię wiary. Dokumenty Kongregacji Nauki Wiary 1966 - 1994. Tarnów 1995 s. 324.

${ }^{5}$ Por. List Apostolski z 18 maja 2000 r., AAS 93 (2001) s. 785-788, por. T. R a k o c z y: Rezerwacje przestepstw kanonicznych w rozumieniu Listu Apostolskiego Kongregacji Nauki Wiary z 2001 i KPK z 1983. „Warmińskie Wiadomości Archidiecezjalne”. R. 2004 nr 5-6 s. 81-86.

${ }^{6}$ M. P a stu sz k o: Najświętsza Eucharystia wedlug Kodeksu Prawa Kanonicznego Jana Pawla II. Kielce 1997 s. 151. 
Sobór uczyl w tej kwestii, że: [...] ci, którzy świadomi sq ciężkiego grzechu, jakkolwiek sqdziliby, że za niego żalujq, o ile mogq mieć spowiednika, powinni najpierw odbyć sakramentalnq spowiedź. Jeśliby zaś ktoś odważyl się inaczej uczyć, glosić albo uparcie twierdzić, lub też bronić w publicznej dyskusji, tym samymniech będzie wylaczony?.

Wskazany przepis prawny zawarty w kan. 916 KPK potwierdza cytowane nauczanie Kościoła. Wynikają z niego niezmiennie dwie normy prawne dotyczące dwóch różnych sytuacji, w jakich może znaleźć się wierny. Pierwsza z nich dotyczy zakazu przystapienia do Komunii św. o charakterze bezwzględnym i dotyczy osób, które są obciążone grzechem ciężkim i mają możliwość wyspowiadania się. Tym wiernym nie wolno jest przystapić do Komunii Eucharystycznej. Druga norma dotyczy tych wiernych, którzy są co prawda obarczeni grzechem ciężkim, ale sa pozbawieni możliwości wyspowiadania się. Wspomniany zakaz wiąże ich zatem względnie. W takiej sytuacji moga przystapić do Komunii Eucharystycznej. Wcześniej jednak winni wzbudzić akt żalu doskonalego, który zakłada zamiar wyspowiadania się jak najszybciej, tj. przy najbliższej możliwości ${ }^{8}$. Prawodawca domaga się ponadto, aby przystapienie do Eucharystii w sytuacji grzechu ciężkiego było umotywowane poważną przyczyną. Nie jest więc wystarczający zwykly zamiar ${ }^{9}$. Zasada ta może mieć swoją aplikację w sytuacji, gdy nie ma szafarza sakramentu pokuty albo gdy jest, ale wierny nie zdażylby wyspowiadać się, przed przyjęciem Eucharystii. Huels wskazuje ponadto, że poważny powód, oprócz niebezpieczeństwa śmierci, może zaistnieć także w sytuacji, gdy dostępny jest jedynie spowiednik znany osobiście i wyspowiadanie się u niego wiazaloby się ze skrępowaniem ${ }^{10}$. Argument ten wydaje się jednak dyskusyjny w obliczu zasady, jaka podaje prawodawca w kan. 960, stanowiąc o konieczności integralności spowiedzi św. Ilustrując tę normę jakimś przykładem, można wskazać, podobnie jak w przypadku wiernego ukaranego kara latae sententiae, na wiernego, który uczestniczy w ważnej dla niego Eucharystii z racji pogrzebu czy ślubu bliskiej osoby i nie ma możliwości wyspowiadania się. Wierny jednak musi być świadom, że dokonal wszelkich wysiłków, aby wyspowiadać się przed udziałem w Eucharystii i nie odkladal spowiedzi na sam moment bezpośrednio przed sprawowaniem sakramentu. Stan świadomości pozostawania w grzechu ciężkim zabrania przystępowania do Eucharystii i tylko do

\footnotetext{
${ }^{7}$ Sobór Trydencki, sesja. XIII, c. 11, tekst polski. W: Breviarium fidei. Wybór doktrynalnych wypowiedzi Kościola. Oprac. S. G 1 o w a, I. B i e d a. Poznań 1998 s. 406.

${ }^{8}$ A 1 t h a u s: Komentarz do kan. 916. W: Münstericher Kommentar ..., dz. cyt., s. 916/4.

${ }^{9}$ P. Hemperek, W. Góralski, F. Przytuła, J. Bakalarz: Uświęcajace zadanie Kościola ..., dz. cyt., s. 120.

${ }^{10}$ J. M. H u el s: Komentarz do kan. 916. W: J. P. B e a 1, J. A. C ori de n, T. J. Gr e e n: New Commentary on the Cade of Canon Law. New York 2000 s. 1111.
} 
Niej. Warto zwrócić uwagę na to, że analogicznego zakazu nie ma w przypadku przystępowania czy sprawowania pozostalych sakramentów.

\section{Wierni żyjący w jawnym grzechu ciężkim}

Sytuacja staje się bardziej skomplikowana, gdy wierny żyje w grzechu ciężkim, który nosi znamię grzechu ciężkiego jawnego. Taka sytuację prawodawca powszechny normuje w kan. 915 KPK. Stanowi on, że: Do Komunii Swiętej nie należy dopuszczać [...] osób trwajacych z uporem w jawnym grzechu ciężkim. Norma ta, podobnie jak dotycząca wiernych związanych kara ferendae sententia$e$, jest adresowana do szafarza, który ma obowiązek pominąć takie osoby w rozdawaniu Komunii św.

Analizując omawianą zasadę należy odpowiedzieć na rodzące się pytanie o definicję jawnego grzechu ciężkiego, którym operuje prawo. Wykładnię tę podała Stolica Apostolska w Deklaracji z dnia 24 czerwca 2000 r., opracowanej przez dwie Kongregacje, tj. Kongregacje Doktryny Wiary oraz Kongregacje Kultu Bożego i Dyscypliny Sakramentów ${ }^{11}$. Bezpośrednim celem opublikowania niniejszej deklaracji, jak wskazuja jej twórcy, byly poglądy niektórych autorów, którzy sugeruja, używajqc rozmaitych argumentów, że norma kan. 916 KPK nie jest aplikowalna do tych spośród wiernych, którzy rozwiedli się $i$ zawarli powtórny zwiqzek malżeński. Prawodawca stanowi w pkt 2, że sytuacja jawnego grzechu ciężkiego jest w rozumieniu prawa kanonicznego jasna. Ma ona miejsce, gdy zostają spelnione równocześnie trzy warunki. Są nimi mianowicie: grzech ciężki, rozumiany obiektywnie tak, że udzielający Komunii św. nie jest w stanie go ocenić wskutek subiektywnej nieprzypisywalności; uparta trwałość, która oznacza istnienie obiektywnej sytuacji grzechu, który trwa w czasie i jakiej wola indywidualnego czlonka wspólnoty wiernych nie może zakończyć (żadne inne wymagania nie sa konieczne do ustanowienia fundamentalnej ciężkości tej sytuacji w Kościele, jak np. upomnienie czy wcześniejsze ostrzeżenie itd.); zewnętrzny charakter sytuacji ciężkiego grzechu habitualnego ${ }^{12}$. Reasumujac, należy stwierdzić, że osobami żyjącymi w jawnym grzechu ciężim są ci, którzy pozostają w

${ }^{11}$ Tekst angielski Deklaracji w.: http://vatican.va/roman curia/pontifical councils/intrptxt/ documents/rc_pc_interptxt_doc_20000706_declaration_en.html, 2005-03-27, godz. 18:05.

${ }^{12}$ The phrase „and others who obstinately persist in manifest grave sin" is clear and must be understood in a manner that does not distort its sense so as to render the norm inapplicable. The three required conditions are:

a) grave sin, understood objectively, being that the minister of Communion would not be able to judge from subjective imputability;

b) obstinate persistence, which means the existence of an objective situation of sin that endures in time and which the will of the individual member of the faithful does not bring to an end, no other requirements (attitude of defiance, prior warning, etc.) being necessary to establish the fundamental gravity of the situation in the Church;

c) the manifest character of the situation of grave habitual sin. 
oczywistej niezgodzie $\mathrm{z}$ zasadami moralności chrześcijańskiej ${ }^{13}$ i trwają w niej w sposób habitualny.

W kategorii jawnego grzechu ciężkiego mieszczą się zatem osoby rozwiedzione, które zawarly powtórny związek w rozumieniu prawa danego państwa. Wierni ci byli bezpośrednim przedmiotem wskazanej Deklaracji. Stolica Apostolska wypowiadala się na ich temat także wcześniej m.in. w Adhortacji Apostolskiej Familiaris Consortio z dnia 22 listopada 1981 r. Czytamy w niej, że.: Kościól jednak na nowo potwierdza swoja praktykę, opartq na Piśmie Świętym, niedopuszczania do Komunii Eucharystycznej rozwiedzionych, którzy zawarli ponowny zwiqzek malżenski. Nie mogq być dopuszczeni do Komunii Świętej od chwili, gdy ich stan i sposób życia obiektywnie zaprzeczaja tej więzi milości między Chrystusem i Kościolem, która wyraża i urzeczywistnia Eucharystia. Jest poza tym inny szczególny motyw duszpasterski: dopuszczenie ich do Eucharystii wprowadzaloby wiernych w blad lub powodowałoby zamęt, co do nauki Kościola o nierozerwalności malżeństwa ${ }^{14}$. Kościól wielokrotnie powtarzal swoje stanowisko w sprawie niemożliwości przyjęcia Komunii Świętej przez takich wiernych. Zostalo ono wyrażone m.in. w Katechizmie Kościola Katolickiego z dnia 11 października $1992^{15}$ oraz w Liście Kongregacji Nauki Wiary z dnia 14 września $1994^{16}$. Sytuacja prawna osób rozwiedzionych, które zawarly powtórny związek małżeński jest analogiczna w skutkach do sytuacji: małżeństwa na próbę, wolnych związków bez żadnej publicznej więzi, katolików związanych tylko węzlem

${ }^{13}$ P. Hemperek, W. Góralski, F. Przy tuła, J. B a ka la rz: Uświęcajace zadanie Kościola ..., dz. cyt., s. 120.

${ }^{14} \mathrm{FC} 84$.

${ }^{15}$ KKK 1650: $W$ wielu krajach sq obecnie liczni katolicy, którzy na podstawie prawa cywilnego decyduja się na rozwód i zawieraja cywilnie nowy zwiazek. Kościól, będac wierny slowom Jezusa Chrystusa: „Kto oddala żonę swoja, a bierze inna popetnia cudzolóstwo względem niej. I jeśli żona opuści swego męża, a wyjdzie za innego, popelnia cudzolóstwo" (Mk 10, 11-12), nie może uznać nowego zwiazku za ważny, jeśli ważne bylo pierwsze malżeństwo. Jeśli rozwiedzeni zawarli cywilnie drugi zwiqzek malżeński, znajduja sie w sytuacji, która obiektywnie wykracza przeciw prawu Bożemu. Dlatego nie moga oni przystępować do Komunii eucharystycznej tak dlugo, jak dlugo trwa ta sytuacja. Z tego samego powodu nie moga oni petnić pewnych funkcji kościelnych.

${ }^{16}$ Wierny, który żyje na state na sposób matżeński z osobq, która nie jest prawowita matżonka albo prawowitym mężem, nie może przystępować do Komunii świętej, tekst polski w: „L'Osservatore Romano”. Wydanie polskie. R. 15: 1994 nr 11 s. 49-51. Kongregacja Nauki Wiary wypowiedziała się na ten temat także wcześniej, w Liście z dnia 11 kwietnia 1973 r. skierowanym do biskupów w sprawie nauczania Kościola o nierozerwalności malżeństwa. Tekst polski. W: E. S zt af row sk i: Posoborowe Prawodawstwo Kościelne. T. 7 z. 2. Warszawa 1977 s. 197-199, cyt. za: W. Gó ra $1 \mathrm{~s} \mathrm{k} \mathrm{i:} \mathrm{Problem} \mathrm{udzialu} \mathrm{w} \mathrm{życiu} \mathrm{sakramentalnym} \mathrm{osób} \mathrm{żyjacych} w$ niekanonicznych zwiqzkach malżenskich. RNP. T. XIV: 2004 zeszyt 2 s. 100. 
cywilnym. Ich także nie wolno w rozumieniu cytowanego punktu Familiaris consortio dopuścić do Komunii Eucharystycznej ${ }^{17}$.

Niniejszy zakaz nie jest jednak bezwzględny, jeśli chodzi o rozwiedzionych i żyjacych w powtónych zwiazkkach. Jan Paweł II we wskazanej adhortacji, w tym samym jej numerze, wskazuje na możliwość, w której takie osoby mogą przystępować do Eucharystii. Czytamy tam, że: Pojednanie w sakramencie pokuty które otworzyloby drogę do Komunii Eucharystycznej - może być dostępne jedynie dla tych, którzy żalujac, że naruszyli znak Przymierza i wierności Chrystusowi, sq szczerze gotowi na taka forme życia, która nie stoi w sprzeczności z nierozerwalnościq małżeństwa. Oznacza to konkretnie, że gdy mężczyzna i kobieta, którzy dla ważnych powodów - jak na przykład wychowania dzieci - nie mogąc uczynić zadość obowiązkowi rozstania się, postanawiajq żyć w pelnej wstrzemięźliwości, czyli powstrzymywać się od aktów, które przyshuguja jedynie malżonkom. Ta sama regula została przypomniana we wskazanym numerze Katechizmu Kościoła Katolickiego i w omawianym Liście Kongregacji Nauki Wiary. Prawodawca umożliwia przyjmowanie Eucharystii przez osoby żyjace w powtórnych związkach niesakramentalnych, gdy zajdą dwa warunki. Pierwszym z nich jest ważny powód, który usprawiedliwia życie w omawianym związku. Takim może być, jak podają dokumenty Kościola, wychowanie wspólnych dzieci. Jest to przykład najbardziej czytelny, ale nie wyklucza innych, które chociaż nie zostaly wyliczone, muszą być równie poważne. Wychowanie wspólnego potomstwa wchodzi w zakres jednego $\mathrm{z}$ trzech dóbr sakramentu tzw. bonum prolis. Wydaje się, że gdyby pozostawanie w związku nieskakramentalnym bylo usprawiedliwione przez pozostale dobro (dobro malżonków, ponieważ dobro sakramentu i tak nie wchodzi tutaj w grę), powinno ono także zostać wskazane. Skoro jednak go nie wyliczono, prawdopodobnie nie należy brać go pod uwagę. Ostatecznie zatem wydaje się, że trudno byloby znaleźć inne powody o równie poważnej ciężkości.

Drugim warunkiem jest zobowiązanie, jakie maja podjać omawiane osoby. Mają one mianowicie powstrzymać się od aktów malżeńskich. Adhortacja nie wskazuje na podmiot, który mialby odebrać takie zobowiazanie. Nie jest jasne, kto ma nim być. Czy ma być nim przelożony zewnętrzny, czy wystarczający jest spowiednik, czy może wierni powinni podjąć się takiego zobowiązania wlasną powaga.

Według wskazanego Listu Kongregacji Nauki Wiary z dnia 14 września 1994 r. osoby, które żyją w związkach niesakramentalnych, a które podjęly się omawianego zobowiązania winny przystępować do sakramentów tak, aby nie budzić zgorszenia wspólnoty kościelnej. Nie wskazuje się tutaj na wymóg

${ }^{17}$ M. P a st u s z k o: Najświętsza Eucharystia ..., dz. cyt., s. 153. 
przyjmowania sakramentów poza swoją parafią, a jedynie mówi się o trosce dotyczacej uniknięcia zgorszenia.

Podsumowując całość norm prawnych w tej kwestii, należy wskazać, że brakuje konkretnych i szczególowych przepisów wykonawczych. Wydaje się, że przedmiot ich regulacji domaga się, aby zostały opracowane przez poszczególne Konferencje Biskupów. Ten problem nie doczekal się do tej pory wyraźnego opracowania prawnego i budzi spore zamieszanie.

Cytowana uprzednio Deklaracja z dnia 24 czerwca 2000 r. wydana przez Kongregację Nauki Wiary i Kongregację Kultu Bożego i Dyscypliny Sakramentów wskazuje w pkt 3 na troskę pasterska, jaka powinna cechować przełożonego kościelnego w przypadku odmowy udzielenia Eucharystii. Jest on mianowicie zobowiązany do podjęcia wysiłku polegającego na wytlumaczeniu niemożności przystapienia do Komunii Eucharystycznej przez niniejsze osoby. Ostatecznie, gdyby jednak podjęte wysiłki nie daly efektu, szafarz musi odmówić udzielenia Eucharystii. Obie Kongregacje wskazują w pkt 4 Deklaracji, że żaden kościelny autorytet i w żadnym przypadku nie może zdyspensować szafarza Eucharystii z obowiązku pominięcia takich osób ani także nie może wydać norm przeciwnych temu zakazowi.

\section{Przyjęcie Eucharystii od szafarza katolickiego}

Wierni mają obowiązek przyjmowania sakramentów świętych od szafarzy katolickich, przy zachowaniu swobody wyboru obrządku ${ }^{18}$. Zasada ta została wpisana do kan. 923. Prawodawca stanowi, że: Wierni mogq uczestniczyć w Eucharystycznej Ofierze i przyjmować Komunię święta w jakimkolwiek obrzqdku katolickim, z zachowaniem przepisu kan. 844 . Kan. 844 §1, do którego odwoluje się prawodawca, stanowi, że: Katoliccy szafarze udzielaja godziwie sakramentów tylko wiernym katolikom, którzy też godziwie przyjmujq je tylko od katolickich szafarzy $[\ldots]$.

Wierny ma zatem prawo korzystania na zasadzie swobodnego uznania $z$ jakiegokolwiek obrządku katolickiego ${ }^{19}$. Nie wolno mu jednak przyjmować Eucharystii z kościoła czy wspólnoty, które nie maja pelnej wspólnoty z Kościolem

${ }^{18}$ M. P a st u s z k o: Najświętsza Eucharystia ..., dz. cyt., s. 223.

${ }^{19}$ Należy pamiętać także i o tym, że nawet długotrwałe przyjmowanie sakramentów w Kościele Katolickim innego obrządku, niż obrządku chrztu, nie skutkuje zmiana obrządku. Niniejsza zasada została zawarta w normie kan. 112 \$2. por. A 1 t h a u s: Komentarz do kan. 923. W: Münstericher Kommentar ..., dz. cyt., s. 923/2. 
Katolickim z zachowaniem jednakże wyjątku, o którym w kan. $844 \$ 2^{20}$. Zasada wiążącą wiernego jest przyjmowanie Najświętszej Eucharystii z rąk szafarza katolickiego, mimo że jej ważność jest niekwestionowana także w Kościele Wschodnim odlączonym. Przyjęcie Komunii św. z rąk szafarza prawosławnego jest zatem w rozumieniu niniejszej zasady wyjatkiem. Może on zaistnieć po równoczesnym wyczerpaniu się trzech warunków wymaganych w normie wskazanego kan. 844 \$2. Prawodawca wskazuje wlaściwie na trzy pary warunków, domagając się zweryfikowania się jednego z nich w każdej parze. Pary te są następujace: konieczność albo prawdziwy pożytek duchowy; brak niebezpieczeństwa blędu lub indyferentyzmu; fizyczna lub moralna niemożliwość udania się do szafarza katolickiego. Chcąc zilustrować tę normę jakimś przykładem, można wskazać na wiernego, który w swoim subiektywnym sądzie twierdzi, że czerpie większy pożytek duchowy z Eucharystii sprawowanej w świątyni Kościoła Prawosławnego; po wtóre zdaje sobie sprawę z odmienności obu Kościolów i w końcu jest dla niego moralnie niemożliwe udanie się do wlasnej świątyni np. z racji na brak zaufania do miejscowego szafarza katolickiego, który w oczach swojej wspólnoty cieszy się zlą sława. W takich okolicznościach, jak stanowi prawodawca, przyjęcie Eucharystii jest dla wiernego dozwolone, na co wskazuje slowo „wolno wiernym”, a nie np. „wierni są zobowiązani”. Wierni katolicy przyjmując Eucharystię z rąk szafarza prawosławnego winni pamiętać jednak o tym, by nie spowodować zgorszenia i nieufności u chrześcijan wschodnich ze względu na odmienne zwyczaje, gdy chodzi o przyjmowanie Komunii św. Czasami w imię takiego szacunku katolik powinien powstrzymać się od Eucharystii, o ile Kościól Wschodni rezerwuje ją tylko dla swoich wiernych ${ }^{21}$. Należy nadmienić, że obowiązek uczestnictwa w świątecznej Eucharystii nie wiąże wiernego katolika, gdyby znalazł się on w miejscu, w którym istnialaby jedynie świątynia Kościola Prawoslawnego ${ }^{22}$.

\section{Przyjęcie Eucharystii raz dziennie}

Jak stanowi prawodawca powszechny w kan. 917: Kto przyją już najświętszq Eucharystię, może ja ponownie tego samego dnia przyjać jedynie podczas sprawowania Eucharystii, w której uczestniczy, z zachowaniem przepisu kan. 921

${ }^{20}$ J. M. Hu el s: Komentarz do kan. 923. W: J. P. B e a 1, J. A. Corid e n, T. J. Gr e e n: New Commentary ..., dz. cyt., s. 1116.

${ }^{21}$ Papieska Rada do Spraw Jedności Chrześcijan: Dyrektorium Ekumeniczne, 25 marca 1993, pkt 124, tekst polski. „Communio”. Wydanie polskie. R. $1994 \mathrm{nr} 2$.

${ }^{22}$ Regułe tę potwierdza prawodawca powszechny w kan. 1248 §1: Nakazowi uczestniczenia we Mszy świętej czyni zadość ten, kto bierze w niej udzial, gdziekolwiek jest odprawiana w obrzadku katolickim, bądź w sam dzień świąteczny, bądź też wieczorem dnia poprzedzającego. 
$\S 2$. Prawo staje zatem na stanowisku przyjmowania przez wiernego Komunii św. tylko raz dziennie. Jak wynika z przytoczonej wyżej normy nie jest to zasada wiążąca bezwzględnie. Wierny może przyjać Eucharystię powtórnie tego samego dnia bez względu czy tym dniem jest dzień powszedni, niedziela, czy inna uroczystość. Musi zostać jednak zachowany tylko jeden warunek. Mianowicie: po raz drugi można przyjąć Komunię św. podczas sprawowania Eucharystii. Użyte w kanonie słowo iterum było przedmiotem zapytania skierowanego do Komisji Interpretacyjnej. Chodzilo mianowicie o to czy należy je rozumieć jako ,po raz drugi”, czy jako „po raz kolejny”. Oba te thumaczenia są bowiem możliwe w przekładzie wskazanego słowa lacińskiego na język polski. Przyjęcie tej drugiej interpretacji (jako kolejne) otwierałoby wiernym możliwość wielokrotnego przyjmowania Eucharystii w ciagu jednego dnia. Komisja Interpretacyjna przedstawila swoje wyjaśnienie dnia 11 lipca 1984 r., w którym opowiedziała się, że: Wierny, który już przyjąt Eucharystię, może wedlug kan. 917 tego samego dnia przyjąc Komunię Świętq, o ile uczestniczy w Eucharystii ${ }^{23}$.

Racja sformułowania powyższej zasady jest podwójna. Po pierwsze prawodawca promuje udzial wiernych $w$ Eucharystii, zmierzajac do pełnego ich uczestnictwa polegającego na przyjęciu Komunii św. Z drugiej strony chroni przed nadużyciem w przyjmowaniu Eucharystii przez wiernych kierujących się przesądem, ignorancją lub źle ukierunkowaną pobożnościąa ${ }^{24}$.

Niniejsza regula ograniczająca prawo wiernego do Eucharystii, wiąże się z zachęta przyjęcia Komunii św. podczas Mszy św., o której mowa w kan. 918. Jednakże proszqcym o niq dla slusznej racji poza Mszq świętq, należy udzielić, zachowujac obrzędy liturgiczne.

\section{Obowiązek zachowania postu eucharystycznego}

Warunkiem, jaki musi spelnić wierny przed przyjęciem Eucharystii jest zachowanie postu eucharystycznego. Jego przedzial czasowy ulegal na przestrzeni dziejów coraz większemu zlagodzeniu. Niemal od pierwszych wieków istnienia Kościola wierni byli zobowiązani do powstrzymania się od wszelkich pokarmów i napojów od pólnocy. Od zachowania niniejszego obowiazku można bylo odejść w przypadku niebezpieczeństwa śmierci oraz gdy należało spożyć Eucharystię, aby uchronić ją przed zniewagą. Niniejsze unormowania rządzily się kan. $858 \S 1$ KPK z 1917 r. Do czasu promulgacji obecnego Kodeksu przepisy prawne w tej

${ }^{23}$ AAS 76 (1984) 746 cyt. za: A lth a us: tekst niemiecki orzeczenia. W: Münstericher Kommentar ..., dz. cyt., s. $917 / 3$.

${ }^{24}$ J. M. Hu e1 s: Komentarz do kan. 917. W: J. P. B e a 1, J. A. C or ide n, T. J. G r e e n: New Commentary ..., dz. cyt., s. 1112. 
materii ulegaly dalszemu zlagodzeniu ${ }^{25}$. Obecna zasada prawna zostala wpisana do kan. 919 §1 i 3. Prawodawca stanowi w §1, że: Przystępujqcy do najświętszej Eucharystii powinien przynajmniej na godzinę przed przyjęciem Komunii Świętej powstrzymać się od jakiegokolwiek pokarmu i napoju, z wyjatkiem tylko wody $i$ lekarstwa. $\$ 3$ niniejszego kanonu stanowi natomiast, że: Osoby w podeszlym wieku lub zlożone jakqśs chorobq, jak również ci, którzy się nimi opiekuja, mogq przyjąć Najświętszq Eucharystię, chociażby coś spożyli w ciqgu godziny poprzedzajacej. Zasada zachowania postu eucharystycznego wiąże zatem na godzinę przed przyjęciem Komunii św. Nie dotyczy ona osób w podeszlym wieku, chorych oraz ich opiekunów. Obowiazku zachowania postu nie lamie ponadto przyjęcie wody i lekarstw ${ }^{26}$. Prawodawca zachęca wiernych do zachowania dhuższego postu eucharystycznego, na co wskazuje slowo „przynajmniej”. Powstrzymanie się na sześćdziesiąt minut przed przyjęciem Eucharystii stanowi wystarczający i minimalny przedzial czasu. Zachowanie postu eucharystycznego należy liczyć do momentu faktycznego przyjęcia Eucharystii, a nie rozpoczęcia sprawowania Mszy świętej ${ }^{27}$.

Zachowanie postu eucharystycznego dotyczy także kaplana sprawującego Mszę święta. Jednakże obowiązek ten jest zlagodzony przed Eucharystią binowaną czy trynowana. Prawodawca w kan. $919 \$ 2$ stanowiąc o niniejszej zasadzie, pozwala kaplanowi „,coś spożyć”, nie zwalniając go zatem calkowicie z zachowania postu. Rodzi się zatem pytanie o to czy analogiczna zasada obowiązuje wiernego, który przed powtórnym przyjęciem Eucharystii także mógłby coś spożyć. Należy zauważyć, że zarówno wiernego świeckiego jak i wiernego duchownego obowiazuje regula przyjęcia (czy sprawowania) Eucharystii tylko raz dziennie. Wydaje się jednak, że prawodawca pozwala duchownemu na binowanie lub nawet trynowanie ze względu na potrzeby pastoralne czego nie można powiedzieć w przypadku przyjęcia Eucharystii przez wiernego. Dlatego też nie należy aplikować przez analogię możliwości złagodzenia postu w przypadku powtórnego przyjęcia Komunii św. przez wiernego świeckiego.

Także i w przypadku tej zasady należy spytać o możliwość odejścia od niej. Analizowana regula jest niewatpliwie pochodzenia czysto kościelnego, czego z reszta dowodzi historia problemu polegajaca na nieustannym zmniejszaniu wymagań stawianym wiernym w omawianej kwestii. Można zatem od niej dyspensować. Nie jest jednak jasne, kto jest wlaściwym podmiotem upoważnionym z

${ }^{25}$ P. Hemperek, W. Góralski, F. Przy tula, J. B a ka larz: Uświęcajace zadanie Kościola ..., dz. cyt., s. 125; J. M. H u e l s: Komentarz do kan. 919. W: J. P. B e a 1, J. A. C o r i de n, T. J. G r e e n: New Commentary ..., dz. cyt., s. 1113.

${ }^{26}$ M. P a st u s z k o: Najświętsza Eucharystia ..., dz. cyt., s. 187.

${ }^{27}$ J. M. Hu el s: Komentarz do kan. 919. W: J. P. B e a1, J. A. C or i d e n, T. J. Gre e n: New Commentary ..., dz. cyt., s. 1114. 
mocy samego prawa do udzielenia dyspensy czy jest nim biskup diecezjalny, co należy shusznie wywnioskować z kan. $87 \S 1$, czy też ordynariusz miejsca, jak stanowi kan. 85. Ewidentna niejasność wskazanych kanonów nie daje w tej materii zdecydowanej odpowiedzi. Przed KPK 1983 dyspensa od zachowania tego obowiązku była zastrzeżona Stolicy Apostolskiej ${ }^{28}$.

\section{Przyjęcie Eucharystii pod odpowiednią postacią}

Prawodawca w kan. 925 stanowi, że: Komunii Świętej należy udzielać tylko pod postacia chleba, albo zgodnie z przepisami liturgicznymi, pod obiema postaciami; w wypadku zaś konieczności, także pod postaciq wina.

Przyjmowanie Eucharystii tylko pod jedną postacią nie stanowi umniejszenia dostępu do lask sakramentu. Sobór Trydencki uczyl, że wierni przyjmujacy Eucharystię pod jedną postacią przyjmuja calego Chrystusa i prawdziwy Sakrament. Z tego powodu wierni przystępujacy do Komunii św. pod postacia chleba nie są pozbawieni żadnej laski koniecznej do zbawienia. Sobór Trydencki wskazal ponadto, że: $z$ mowy podanej w rozdziale VI św. Jana nie można stusznie wnioskować, że nakazana jest Komunia pod dwiema postaciami (kan. 3), jakkolwiek by ja rozumiano wedlug różnych interpretacji świętych Ojców i Doktorów. Bo ten sam, który powiedzial: „Jeślibyście nie pożywali ciala Syna Czlowieczego i nie pili krwi Jego, nie będziecie mieć życia w sobie" [J 6, 53], powiedzial też: „Kto spożywa ten chleb, żyć będzie na wieki" [J6, 51]. I Ten, co powiedzial: "Kto spożywa Cialo moje i plje krew moja, posiada życie wieczne [J6, 54], powiedzial także: „Chleb, który ja dam, jest ciało moje za życie świata” [J6, 51$].$ Wreszcie Ten, który powiedzial: "Kto spożywa cialo moje i pije krew mojq. przebywa we mnie a ja w nim [J 6, 56], powiedzial równiez: „, Kto spożywa ten chleb, żyć będzie na wieki" $[\mathrm{J} 6,58]^{29}$.

Zasady przyjmowania Eucharystii pod obiema postaciami zostaly przypomniane w Ogólnym Wprowadzeniu do Mszalu Rzymskiego z dnia 6 listopada $2003^{30}$. Prawodawca w pkt. 281 zawiera krótką katechezę wyjaśniającą znaczenie udzielania Eucharystii pod dwoma postaciami. Czytamy mianowicie we wskazanym punkcie, że: W takim znaku ukazuje się $w$ doskonalszym świetle znak Uczty eucharystycznej i jaśniej wyraża się wola dopetnienia nowego i wiecznego przymierza we Krwi Pana; jaśniej też uwydatnia się związek istniejacy pomiędzy Ucztq eucharystycznq, a ucztq eschatologicznq w królestwie Ojca. Sytuacje,

\footnotetext{
${ }^{28}$ Tamże.

${ }^{29}$ Sobór Trydencki, sesja XXI, rozdzial 1, tekst polski. W: Breviarium fidei.., dz. cyt., s. 408.

${ }^{30}$ Tekst polski. W: Ogólne Wprowadzenie do Mszalu Rzymskiego z trzeciego wydania Mszalu Rzymskiego. Rzym 2002. Pallotinum. Poznań 2004.
} 
umożliwiające przyjmowania Komunii Świętej pod dwoma postaciami zostaly wyliczone w pkt. 283 Wprowadzenia. Dokument różnicuje odnośne normy prawne w czterech grupach. Po pierwsze, zachowuje w mocy normy prawne zawarte w rytuale. Po drugie, rozszerza możliwość takiego sposobu na nowe sytuacje. Komunię św. pod dwoma postaciami moga mianowicie przyjmować kaplani, którzy nie moga celebrować ani koncelebrować; diakon i uslugujacy, którzy pełnią swoje funkcje we Mszy św.; czlonkowie zgromadzeń we Mszy konwentualnej oraz Mszy zgromadzenia, alumni seminarium, uczestnicy rekolekcji lub zebrania jakiegoś zespolu duszpasterskiego. Po trzecie, Wprowadzenie zawiera delegację ustawową dla biskupa diecezjalnego, który w swoim Kościele partykularnym może wskazać na jeszcze inne sytuacje, jakie uprawniaja wiernych do przyjmowania Komunii św. pod dwoma postaciami. Wśród nich moga znaleźć się i takie, których ostateczne wykonanie będzie należalo do kaplana sprawującego pasterska pieczę nad powierzoną mu wspólnotą. Czwarta grupa jest objęta delegacja dla Konferencji Biskupów. Zostaly one upoważnione, wedlug ich przekonania, do wydania norm dotyczących rozszerzenia możliwości udzielania Komunii św. pod dwoma postaciami. Normy te wymagaja jednak do swej ważności uzyskania recognitio ze strony Stolicy Apostolskiej.

W przypadku udzielania Komunii św. pod dwoma postaciami należy pouczyć wiernych, tak, aby zostalo wykluczone niebezpieczeństwo znieważenia Najświętszego Sakramentu, a sam obrzęd nie okazal się trudny do wykonania z powodu zbyt dużej liczby uczestników lub z innej przyczyny. Jak wskazują pkt. 285, 286, 287 Ogólnego Wprowadzenia do Mszalu Rzymskiego, przyjeccie Eucharystii pod dwoma postaciami może odbywać się zarówno poprzez udzielenie osobno postaci chleba $\mathrm{i}$ wina lub poprzez zanurzenie postaci chleba $\mathrm{w}$ postaci wina. Konferencja Episkopatu Polski ustalila, że Komunii św. pod dwiema postaciami należy na terenie diecezji polskich udzielać ,przez zanurzenie” (per intinctionem).

Ogólne Wprowadzenie do Mszału Rzymskiego nie wyjaśnia sytuacji usprawiedliwiającej konieczności udzielenia Komunii św. tylko pod postacią wina. Należy suponować, że taki sposób przyjeccia Eucharystii podyktowany będzie jedynie racjami poważnymi. Kongregacja Swiętego Oficjum stwierdzala w latach 1950 - 60, że omawiany powód może zaistnieć w przypadku osób chorych, które są niezdolne do przyjęcia Komunii św. pod postacią chleba. Wydaje się, że takie powody także i obecnie mogą thumaczyć wyjątek od zasady ${ }^{32}$.

${ }^{31}$ L. A d a mow ic z: Wprowadzenie do prawa o sakramentach swietych wedlug Kodeksu Prawa Kanonicznego oraz Kodeksu Kanonów Kościolów Wschodnich. Lublin 1999 s. 118.

${ }^{32}$ J. M. Hu e1 s: Komentarz do kan. 925. W: J. P. B e a 1, J. A. C or i d e n, T. J. G r e e n: New Commentary ..., dz. cyt., s. 1118. 


\section{Postawa towarzysząca przyjęciu Eucharystii}

KPK z 1983 r. nie normuje zagadnienia sposobu przyjęcia przez wiernego Eucharystii. Prawodawca w szczególności nie podaje zasady czy wierny jest zobowiązany do przyjęcia jej klęcząc czy stojąc; a także czy szafarz winien podać Najświętszy Sakrament do ust czy może położyć Go na rękę przyjmujacego. Stolica Apostolska nie pominęla jednak tych ważnych zagadnień milczeniem. Instrukcja $\mathrm{z}$ dnia 1 grudnia 1980 r. Inestimabile donum zawiera bowiem delegację ustawową upoważniająca poszczególne Konferencje Biskupów do wydania szczególowych norm prawnych w tej materii. Ta sama delegacja zostala przypomniana przez Kongregację Kultu Bożego i Dyscypliny Sakramentów we Wprowadzeniu teologiczno-pastoralnym do obrzędów Komunia Święta i kult tajemnicy Eucharystii poza Mszq święta z dnia 25 stycznia 1994, w nr 21. Kongregacja stanowi m.in., że: Zgodnie z wielowiekowq tradycjq przy udzielaniu Komunii Świętej należy zachować zwyczaj skladania czastki konsekrowanego chleba na języku przyjmujacych Komunię. Konferencje Biskupów mogq jednak postanowić, żeby na podlegtym im terenie przyjmowano Komunię święta także przez skladanie konsekrowanego chleba na rękach wiernych, byleby nie zaistnialo niebezpieczeństwo braku czci lub powstania wśród wiernych falszywych opinii o Najświętszej Eucharystii. Decyzja taka wymaga zatwierdzenia Stolicy Apostolskiej. Pierwszym wnioskiem, który nasuwa się po lekturze wskazanej normy jest taki, że Stolica Apostolska wskazuje na przyjmowanie Komunii św. do ust w postawie klęczącej na sposób bardziej tradycyjny oparty na wielowiekowej tradycji. Przyjmowanie Komunii św. na rękę należy traktować jako odejście od niniejszej reguly i jako sposób „nowy ${ }^{\text {"33 }}$.

Realizując delegację ustawową wpisaną do cytowanej Instrukcji, Konferencja Episkopatu Polski, wydala dekret ogólny z dnia 11 grudnia 1980 r., w którym wskazuje się, że jedynym zwyczajnym sposobem przyjmowania Komunii św. jest sposób na klęcząco, do ust. Od tej zasady można odejść tylko w trzech przypadkach. Pierwszy z nich jest usprawiedliwiony przez thok panujący w świątyni; drugi może mieć miejsce, gdy Msza św. sprawowana jest na zewnątrz, a jest wlaśnie po deszczu. Trzeci wyjątek dotyczy osób obciążonych kalectwem lub chorobą, których nie można obligować do klęczenia ze względu na ich stan ${ }^{34}$. Każdy ze wskazanych wyjatków odnosi się do sytuacji przyjęcia Komunii św. na stojaco. Żaden nie usprawiedliwia przyjęcia Eucharystii na rękę. Konferencja Episkopatu Polski wydała ponadto Instrukcję z dnia 11 marca 1987 r. w związku z wy-

\footnotetext{
${ }^{33}$ Por. P. M a j e: Normy prawno-liturgiczne o przyjmowaniu Komunii świętej na rękę. PK 12 (2000) s. 79-93.

${ }^{34}$ Przepisy wykonawcze $z$ dnia 11 grudnia 1980 roku do Instrukcji Kongregacji d o Spraw Sakramentów i Kultu Bożego ,Inestimabile donum” $z$ dnia 3 kwietnia 1980 roku. W: L. A d a mow i c z: Wprowadzenie ..., dz. cyt., s. 116.
} 
daniem nowego mszału oltarzowego. Porusza ona także odnośne zagadnienie. Tym razem normy prawne w niej zawarte brzmią nieco bardziej liberalnie. Czytamy mianowicie, że Komunii św. udziela się przez podanie Hostii wprost do ust i że wierni przyjmuja Eucharystię w postawie klęczącej. Konferencja Episkopatu dopuszcza jednak dość daleko idace wyjatki od tej zasady, ponieważ, jak stanowią Biskupi, wierni mogą również stać, gdy przemawiają za tym szczególne okoliczności. Nie zostaly one nawet egzemplarycznie wymienione. Jeżeli natomiast udziela się Komunii św. pod dwoma postaciami, wierni maj a przyją́ postawę stojąca. Ta norma nie zostala w żaden sposób skomentowana. Nie zostalo wskazane, co mialoby usprawiedliwiać zmianę postawy w takim przypadku.

Analizując wskazane zasady prawne, należy spytać o stronę formalną. Konferencja Biskupów, w rozumieniu kan. $455 \mathrm{KPK}$, może wydawać dekrety ogólne, jeśli zostala do tego upoważniona przez delegację ustawową. Może to także czynić wskutek wlasnej inicjatywy. Zawsze jednak projekt dekretu ogólnego do swojej promulgacji wymaga wcześniejszej zgody Stolicy Apostolskiej. Może zostać do niej zgloszony, jeśli opowie się za nim co najmniej dwie trzecie biskupów danej Konferencji majacej głos stanowczy. Sposób udzielania Komunii św. rzeczywiście należy do kompetencji Konferencji Biskupów. Wniosek taki plynie z cytowanej już Instrukcji Inestimabile donum, która wyraźnie deleguje do tego Konferencję Biskupów i tylko ją. Decyzja zatem o sposobie udzielania Eucharystii winna zostać wydana w drodze dekretu ogólnego tak, jak stalo się to w roku 1980. Ewentualna zmiana tej decyzji powinna nastapić w drodze nowego dekretu ogólnego, potwierdzonego przez Stolicę Apostolską, a nie poprzez wydanie Instrukcji.

Prawodawca powszechny nazywa Eucharystię Najczcigodniejszym Sakramentem i zachęca wiernych do jak najczęstszego przyjmowania Go. Ten sam prawodawca konstruuje jednak zasady ograniczające prawo wiernych do przyjmowania Eucharystii. KPK wylicza ich siedem. Omawiane reguly zamykaja wiernym drogę do przyjęcia Eucharystii albo w ogóle, albo tylko częściowo. Tylko jedna z nich wyplywa z prawa Bożego. Jest nią mianowicie zakaz przyjęcia Eucharystii w sytuacji grzechu ciężkiego. Pozostale sa pochodzenia czysto kościelnego.

Jeśli chodzi o zasady należące do pierwszej ze wskazanych grup, to należy zauważyć, że mimo tak dużego rygoru prawnego, tylko jedna ze wskazanych zasad obowiązuje bezwzględnie. Chodzi mianowicie o zakaz przyjmowania Eucharystii przez wiernych ukaranych na forum zewnętrznym. Wskazany stan kanoniczny wiernych skutkuje tym, że szafarz ma obowiązek odmówienia udzielenia Komunii św. Zasada ta jest ustanowienia kościelnego. Prawodawca przewi- 
duje więc możliwość odejścia od zakazu plynącego z prawa Bożego, a nie przewiduje możliwości odejścia od zakazu czysto kościelnego. Odejście od pozostalych regul z pierwszej grupy jest obwarowane okolicznościami proporcjonalnymi do powagi zakazu i zawsze wskazuje go sam prawodawca. W przypadku wiernych żyjących w grzechu ciężkim Kodeks wyróżnia sytuację grzechu jawnego i niejawnego. Cenne dla kanonistyki jest niewatpliwie jednoznaczne zdefiniowanie pierwszej z nich i wskazanie, że pozostają w niej osoby rozwiedzione, które zawarly powtórny zwiazek cywilny. 
